\title{
Characterization of Clostridium perfringens Isolates Collected from Three Agricultural Biogas Plants over a One-Year Period
}

\author{
Lorine Derongs ${ }^{1}$, Céline Druilhe ${ }^{1}$, Christine Ziebal ${ }^{1}$, Caroline Le Maréchal ${ }^{2}{ }^{\circledR}$ and \\ Anne-Marie Pourcher ${ }^{1, *}$ \\ 1 INRAE, OPAALE Research Unit, CS 64427, F-35044 Rennes, France; lorine.derongs@inrae.fr (L.D.); \\ celine.druilhe@inrae.fr (C.D.); christine.ziebal@inrae.fr (C.Z.) \\ 2 ANSES, Ploufragan-Plouzané-Niort Laboratory, Hygiene and Quality of Poultry and Pig Products Unit, \\ BP53, F-22440 Ploufragan, France; caroline.lemarechal@anses.fr \\ * Correspondence: anne-marie.pourcher@inrae.fr; Tel.: +33-(2)-2348-2137
}

Received: 1 July 2020; Accepted: 24 July 2020; Published: 29 July 2020

\begin{abstract}
Digestate produced by agricultural biogas plants (BGPs) may contain pathogenic bacteria. Among them, Clostridium perfringens deserves particular attention due to its ability to grow under anaerobic conditions and persist in amended soil. The aim of this study was to examine the potential pathogenicity and the antimicrobial resistance of $C$. perfringens in manure and digestate collected from three agricultural biogas plants (BGPs). A total of 157 isolates (92 from manure, 65 from digestate) were screened for genes encoding seven toxins (cpa, cpb, etx, iap cpe, netB, and cpb2). The 138 cpa positive isolates were then screened for $\operatorname{tet} A(\mathrm{P}), \operatorname{tet} B(\mathrm{P}), \operatorname{tet}(\mathrm{M})$, and $\operatorname{erm}(\mathrm{Q})$ genes and tested for antimicrobial susceptibility. The toxinotypes identified in both manure and digestate were type $\mathrm{A}$ ( $78.3 \%$ of the isolates), type $\mathrm{G}(16.7 \%)$, type C (3.6\%), and type $\mathrm{D}(1.4 \%)$, whereas none of the isolates were type F. Moreover, half of the isolates carried the $c p b 2$ gene. The overall prevalence of tet $A(\mathrm{P})$ gene alone, $\operatorname{tet} A(\mathrm{P}) \operatorname{tet} B(\mathrm{P})$ genes, and $\operatorname{erm}(\mathrm{Q})$ gene was $31.9,34.8$, and $6.5 \%$, respectively. None of the isolates harbored the tet $(\mathrm{M})$ gene. Multiple antimicrobial resistant isolates were found in samples that were collected from all the manure and digestates. Among them, $12.3 \%$ were highly resistant to some of the antibiotics tested, especially to clindamycin (MIC $\geq 16 \mu \mathrm{g} / \mathrm{mL}$ ) and tilmicosin (MIC $>64 \mu \mathrm{g} / \mathrm{mL}$ ). Some isolates were highly resistant to antibiotics used in human medicine, including vancomycin (MIC $>8 \mu \mathrm{g} / \mathrm{mL}$ ) and imipenem (MIC $>64 \mu \mathrm{g} / \mathrm{mL}$ ). These results suggest that digestate may be a carrier of the virulent and multidrug resistant $C$. perfringens.
\end{abstract}

Keywords: C. perfringens; mesophilic anaerobic digestion; manure; digestate; toxinotypes; antimicrobial susceptibility

\section{Introduction}

The number of biogas plants has increased considerably in Europe in the last decade (from 6227 installations in 2009 to 18,202 in 2018) [1], most of them operating with agricultural substrates. On-farm anaerobic digestion converts livestock manure into biogas and digestate, and the latter is commonly applied to agricultural soils. However, the spread of zoonotic pathogens and antibiotic resistant bacteria that are potentially present in digestate raises serious concerns. Among these bacteria, Clostridium perfringens, which causes food poisoning in humans and enteric diseases in domestic animals [2], deserves particular attention due to its persistence in soil amended with manure, digestate, or manure compost [3-5]. Clostridia are also suspected of playing a role in the dissemination of antibiotic resistance genes in manure-amended soil [4-6]. Moreover, C. perfringens has been suggested to be a reservoir for conjugative antimicrobial resistance genes $[7,8]$. 
The land application of manure may result in continuous exposure of the agricultural environment to pathogenic and antibiotic resistant bacteria [5]. This raises issues of human health and food safety [9]. Indeed, once contaminated livestock effluents are applied, direct transfer of pathogens to crops and animals may occur [10]. To date, there is no evidence of environmental transmission of C. perfringens, whether or not the bacterium is resistant to antibiotics but one possible transmission route to humans or animals is through the consumption of vegetables contaminated by livestock manure $[11,12]$. Whether anaerobic digestion of manure can reduce the environmental exposure to antimicrobial-resistant $C$. perfringens shed by farm animals has to be dully addressed. Given the increasing number of reports of antimicrobial resistance in anaerobes over the past two decades [13], it is important to examine the potential pathogenicity and antimicrobial profiles of $C$. perfringens present in digested manure before its application on agricultural land.

C. perfringens is a Gram-positive anaerobic spore forming bacterium that is responsible for various diseases, including food poisoning, gas gangrene, enteritis necroticans, and enterotoxemia [14]. It is also involved in antibiotic-associated diarrhea [15]. This bacterium is estimated to be the third most common bacterial cause of food-poisoning cases in the United States [16], and is the third most common cause of foodborne outbreaks in France [17]. C. perfringens produces more than 20 toxins and hydrolytic enzymes $[18,19]$. The species is divided into seven types, $A$ to $G$, according to the presence and combination of four major toxins $(\alpha, \beta, \varepsilon$ and $\iota)$ encoded by genes $c p a, c p b$, etx, and iap, and two minor toxins (enterotoxin CPE and NetB) encoded by genes cpe and netB $[15,19]$. It also produces the $\beta 2$ toxin encoded by the $c p b 2$ gene, which is implicated in several animal gastrointestinal diseases [20] and it is found in different $C$. perfringens toxinotypes [18].

Besides carrying toxin genes, the plasmids harbored by C. perfringens also carry genes conferring resistance to antibiotics. The resistance of $C$. perfringens isolates to tetracycline, clindamycin, lincomycin, and erythromycin has been reported in animals [21,22]. Tetracycline resistance plasmids are the most common antibiotic resistance plasmids in C. perfringens [23]. The genes $\operatorname{tet} A(\mathrm{P})$ and $\operatorname{tet} B(\mathrm{P})$ are frequently associated with tetracycline resistance $[24,25]$ and the genes erm $(\mathrm{B})$ or $\operatorname{erm}(\mathrm{Q})$ have been associated with macrolide-lincosamide-streptogramin B resistance $[23,26]$, the $\operatorname{erm}(\mathrm{Q})$ gene being the most common erythromycin resistance determinant reported in C. perfringens. Only a few studies have examined the antimicrobial susceptibility of $C$. perfringens isolates that were collected from agricultural environments. High resistance to tetracycline has been reported in isolates from piglets, chickens, or cattle [24,27-29]. Moreover, $63 \%$ and $38.4 \%$ of C. perfringens isolates collected from soil in the United States [28] and in Greece [30] were resistant to tetracycline. Soge et al. [8] also reported that the $\operatorname{tet} A(\mathrm{P})$ gene was common in isolates in water and soil. Despite the ability of $C$. perfringens to transfer antibiotic resistance via bacterial conjugation [7] and its ability to survive under conditions found in mesophilic anaerobic digesters (MAD) [31,32], information is lacking on the antimicrobial susceptibility of resistant C. perfringens isolates in digestate intended for land application.

The aims of this study were (i) to identify the toxinotype and the antimicrobial resistance profiles of C. perfringens isolates in digestates originating from three agricultural biogas plants and (ii) to compare the profiles with $C$. perfringens isolates in manure that was collected in the same biogas plants.

\section{Materials and Methods}

\subsection{Biogas Plants and Sample Collection}

The samples were collected from three on-farm biogas plants (BGPs) located in a same area (within a distance of less than $120 \mathrm{~km}$ ), fed with manure and co-substrates of vegetable origin, the proportion of which depending on the BGP (Table S1). BGP1 and BGP3 were fed with liquid pig manure. BGP2 manure mainly comprised liquid dairy manure $(\geq 86 \%)$ and to a lesser extent, solid poultry manure.

Each BGP was sampled eight times (at six-week intervals) from May 2017 to July 2018. Prior to sampling, the liquid manure in the storage tank and in the digester was mixed. At each sampling date, liquid manure and raw digestates were collected using three $10 \mathrm{~L}$ buckets for each type of matrix. 
Samples from each bucket were transferred into $1 \mathrm{~L}$ sterile flasks. A total of 48 samples per BPG were analyzed ( 2 matrices $\times 3$ replicates $\times 8$ sampling dates). Moreover, as poultry manure was not systematically present in BGP2, only three samples were collected during the sampling period. Microbiological analyses were performed within $4 \mathrm{~h}$ after sampling.

\subsection{Isolation of C. perfringens}

Samples ( $25 \mathrm{~g}$ ) of manure or digestate were homogenized in $225 \mathrm{~mL}$ of peptone water. Tenfold serial dilution of the suspensions was performed. C. perfringens was isolated according to the standard ISO method 7937:2005-02 [33]. Briefly, Trytone sulfite Cycloresrin agar (TSC, Thermo Fisher Scientific, Courtaboeuf, France) was poured into a Petri dish containing $1 \mathrm{~mL}$ of each serial dilution. After the solidification of the agar, an overlayer of $10 \mathrm{~mL}$ of TSC was added. The plates were incubated under anaerobic conditions while using anaerobic jars with gaspack (AnaeroGen, Thermo Scientific, Courtaboeuf, France) at $37^{\circ} \mathrm{C}$ for $20 \mathrm{~h} \pm 2 \mathrm{~h}$. Five black colonies were randomly selected on a plate containing between five and 10 colonies of presumptive $C$. perfringens and transferred into thioglycolate broth (Thermo Fisher Scientific, Courtaboeuf, France). The tubes were incubated under anaerobic conditions at $37^{\circ} \mathrm{C}$ for $18 \mathrm{~h} \pm 2 \mathrm{~h}$. Five drops of each thioglycolate culture were transferred into Lactose Sulfite Broth (Biokar Diagnostics, Allonne, France). After incubation at $46{ }^{\circ} \mathrm{C}$ for $18 \mathrm{~h} \pm 2 \mathrm{~h}$ in a water bath, the tubes exhibiting gas production and blackening of the culture medium were considered positive. At each sampling date, all of the confirmed colonies were purified and suspended in 50\% glycerol/50\% Brain Heart Infusion Broth (BHI, Thermo Fisher Scientific, Courtaboeuf, France) before being stored at $-80^{\circ} \mathrm{C}$. A total of 157 isolates were collected from the three BGPs (Table 1).

Table 1. Distribution of the isolates collected from the three biogas plants (BGPs).

\begin{tabular}{cccccccc}
\hline & \multicolumn{2}{c}{ BGP1 } & \multicolumn{3}{c}{ BGP2 } & \multicolumn{2}{c}{ BGP3 } \\
\hline Matrix & Manure & Digestate & $\begin{array}{c}\text { Dairy } \\
\text { Manure }\end{array}$ & $\begin{array}{c}\text { Poultry } \\
\text { Manure }\end{array}$ & Digestate & Manure & Digestate \\
\hline $\mathrm{Nb}$ isolates & 24 & 21 & 25 & 14 & 19 & 29 & 25 \\
\hline
\end{tabular}

\subsection{DNA Extraction}

All of the isolates were cultured on Wilkins-Chalgren agar (WICH, Thermo Fisher Scientific, Courtaboeuf, France). After incubation at $37^{\circ} \mathrm{C}$ for $24 \mathrm{~h}$ under anaerobic conditions, ca. $40 \mathrm{mg}$ of pure culture were removed with a sterile swab and transferred into a $2 \mathrm{~mL}$ tube. DNA extractions were performed using the Nucleospin ${ }^{\circledR}$ Microbial DNA kit (Macherey-Nagel, Hoerdt, France) according to the supplier's recommendations. The DNA was eluted from the silica column in a $100 \mu \mathrm{L}$ elution buffer $(5 \mathrm{mM}$ Tris/ $\mathrm{HCl}, \mathrm{pH} 8.5)$ and then stored at $-20^{\circ} \mathrm{C}$. DNA purity and concentration were determined by measuring absorption at 260 and $280 \mathrm{~nm}$ while using a BioPhotometer Spectrophotometer (Eppendorf, Montesson, France).

\subsection{Determination of the Toxin Genotype and Search for Antibiotic Resistance Genes}

Real-time PCR targeting the four major toxin genes (cpa, cpb, etx, and iap), and three minor toxin genes (cpe, netB, and $c p b 2$ ) was carried out to genotype the $C$. perfringens isolates (Table 2). Strain 103,009,089 from the ANSES (French Agency for Food, Environmental and Occupational Health and Safety) strain collection and strains CIP 103409 ${ }^{\mathrm{T}}$, CIP 106527, CIP 105568, CIP 106156, and CIP 104612 from the Institut Pasteur Collection were used as positive controls.

Four antibiotic resistance genes that may be carried by $C$. perfringens $(\operatorname{tet} A(\mathrm{P}), \operatorname{tet} B(\mathrm{P}), \operatorname{tet}(\mathrm{M})$, and erm $(\mathrm{Q})$ ) were detected by real-time PCR (Table 2). A strain of C. perfringens and a strain of Clostridioides difficile, kindly provided by Dr. O. Firmesse (Anses, Maisons-Alfort, France) and Dr. F. Barbut (Saint-Antoine Hospital, Paris, France), respectively, were used as positive controls for $\operatorname{tet} A(\mathrm{P})$, tet $B(\mathrm{P})$, and erm $(\mathrm{Q})$ genes (C. perfringens $175 \mathrm{BCL} 67)$, and for tet(M) (C. difficile CD17_412). 
Real-time PCRs were performed using a Bio-Rad CFX96 real-time PCR machine with Bio-Rad CFX Manager software, version 1.1 (Bio-Rad, Marnes-la-coquette, France) in a final volume of $25 \mu \mathrm{L}$. The reaction mixture consisted of $12.5 \mu \mathrm{L}$ of IQ SYBR Green Supermix (Bio-Rad, Marnes-la-coquette, France), a $400 \mathrm{nmol} / \mathrm{L}$ concentration of each primer, $2 \mu \mathrm{L}$ of $1 / 10$ diluted DNA, and $9.5 \mu \mathrm{L}$ of water. Negative controls without DNA were also prepared. PCR preparation was performed while using the epMotion 5070 automated pipetting station (Eppendorf, Montesson, France).

The Real-time PCR program for the target gene included one cycle at $94{ }^{\circ} \mathrm{C}$ for $5 \mathrm{~min}, 40$ cycles at $94{ }^{\circ} \mathrm{C}$ for $20 \mathrm{~s}$, one cycle at $55^{\circ} \mathrm{C}$ for $30 \mathrm{~s}$, and one cycle at $72{ }^{\circ} \mathrm{C}$ for $30 \mathrm{~s}[34,35]$. The melting curve of the amplification products was analyzed at the end of each qPCR (temperature range $65{ }^{\circ} \mathrm{C}$ to $95^{\circ} \mathrm{C}$ ). Analysis of the melting curve of the standard replicates only yielded one peak resulting from the specific amplification of the target gene. For a given gene, the amplification of the correct PCR fragment was verified by comparing the cycling threshold value and the melting curve of the standard PCR product with each environmental isolate PCR product.

Table 2. Primers used for the detection of C. perfringens toxin genes and antimicrobial resistance genes.

\begin{tabular}{|c|c|c|c|c|}
\hline Gene & Primers & Sequences $\left(5^{\prime}-3^{\prime}\right)$ & Amplicon Size (bp) & Reference \\
\hline \multirow{2}{*}{ cpa } & CPA5L & AGTCTACGCTTGGGATGGAA & \multirow{2}{*}{900} & [35] \\
\hline & CPA5R & TTTCCTGGGTTGTCCATTTC & & \\
\hline \multirow{2}{*}{$c p b$} & CPBL & TCСТTTCTTGAGGGAGGATAAA & \multirow[b]{2}{*}{611} & [35] \\
\hline & CPBR & TGAACCTCCTATTTTGTATCCCA & & \\
\hline \multirow{2}{*}{ iap } & CPIL & AAACGCATTAAAGCTCACACC & \multirow{2}{*}{293} & [35] \\
\hline & CPIR & CTGCATAACCTGGAATGGCT & & \\
\hline \multirow[b]{2}{*}{ etx } & CPETXL & TGGGAACTTCGATACAAGCA & \multirow{2}{*}{396} & [35] \\
\hline & CPEXTR & TTAАСТСАТСТСССАТАAСТGСАС & & \\
\hline \multirow{2}{*}{ cpe } & CPEL & GGGGAACCCTCAGTAGTTTCA & \multirow{2}{*}{506} & [35] \\
\hline & CPER & ACCAGCTGGATTTGAGTTTAATG & & \\
\hline \multirow{2}{*}{$c p b 2$} & CPB2L & CAAGCAATTGGGGGAGTTTA & \multirow[b]{2}{*}{200} & [35] \\
\hline & CPB2R & GCAGAATCAGGATTTTGACCA & & \\
\hline \multirow[b]{2}{*}{ net $B$} & AKP78 & GCTGGTGCTGGAATAAATGC & \multirow{2}{*}{383} & [34] \\
\hline & AKP79 & TCGCCATTGAGTAGTTTCCC & & \\
\hline \multirow{2}{*}{$\operatorname{erm}(\mathrm{Q})$} & GE 350 & GAAGAGTTAAATYCACCAACTGA & \multirow{2}{*}{84} & This study \\
\hline & GE 352 & ACTCTCTCTAGGTATTCCCA & & \\
\hline \multirow{2}{*}{ tet $A(\mathrm{P})$} & GE 353 & TGTAGCACAGATTGTATGGGGA & \multirow{2}{*}{124} & This study \\
\hline & GE 355 & CCCTGCTTGTGCTCCCTTTA & & \\
\hline \multirow{2}{*}{$\operatorname{tet} B(\mathrm{P})$} & GE 359 & TTTTGGGCGACAGTAGGCTT & \multirow{2}{*}{90} & This study \\
\hline & GE 361 & TGGCAATGACCCTACTGAAACA & & \\
\hline \multirow{2}{*}{ tet $(\mathrm{M})$} & GE 362 & GCTATTGCCACAGAGAGAGAGA & \multirow{2}{*}{127} & This study \\
\hline & GE 364 & CGGGTCACTGTCGGAGATTT & & \\
\hline
\end{tabular}

\subsection{Testing Antimicrobial Susceptibility}

Antimicrobial susceptibility was tested on the 138 cpa-positive isolates using the commercially available Sensititre ${ }^{\mathrm{TM}}$ Bovine/porcine according to the manufacturers' instructions (ThermoFisher Diagnostics, Courtaboeuf, France). Seventeen antimicrobial agents commonly used for the treatment of livestock diseases were tested. They included $(\mu \mathrm{g} / \mathrm{mL}$ ) penicillin (PEN, $0.12-8)$, ampicillin (AMP, 0.25-16), ceftiofur (TIO, 0.25-8), tartrate tylosin (TYLT, 0.5-32), tulathromycin (TUL, 1-32), tilmicosin (TIL, 4-64), tiamulin (TIA, 0.5-32), chlortetracycline (CTET, 0.5-8), oxytetracycline (OXY, 0.5-8), danofloxacin (DANO, 0.125-1), enrofloxacin (ENRO, 0.125-2), trimethoprim/sulfamethoxazole (SXT, 2/38), sulfadimethoxine (SDM, 256), neomycin (NEO, 4-32) florfenicol (FFN, 0.25-8), spectinomycin (SPE, 8-64), and clindamycin (CLI, 0.25-16). The plates contained three wells not inoculated with antibiotics as growth controls. The microplates were sealed with a micro-perforated film and incubated at $37^{\circ} \mathrm{C}$ for $24 \mathrm{~h}$ under anaerobic conditions. 
The isolates were incubated in WICH broth at $37^{\circ} \mathrm{C}$ in under anaerobic conditions. Overnight bacterial cultures were adjusted to $0.5 \mathrm{McF}$ arland turbidity standard in WICH broth, and $50 \mu \mathrm{L}$ of the diluted bacterial suspensions ( $c a .10^{5} \mathrm{CFU} /$ well) were added to each well.

Among the 138 cpa-positive isolates, 14 isolates originated from the three BGPs were selected for their high resistance to antibiotics of the Sensititre ${ }^{\mathrm{TM}}$ Bovine/porcine plate. Their susceptibility to antimicrobial agents commonly used against anaerobic human pathogens were tested with the Sensititre ${ }^{\mathrm{TM}}$ Anaerobe MIC plate (WICH, Thermo Fisher Scientific, Courtaboeuf, France) according to the manufacturers' instructions (ThermoFisher Diagnostics, Dardilly, France). The plate contained 14 antimicrobial agents $(\mu \mathrm{g} / \mathrm{mL})$ : metronidazole (MRD, 0.5-32), linezolid (LZD, 1-16), moxifloxacin (MXF, 0.12-4), tigecycline (TGC, 1-32), piperacillin-tazobactam constant 4 (P/T4, 2/4-64/4), piperacillin (PIP, 2-64), penicillin (PEN, 0.06-8), vancomycin (VAN, 1-8), amoxicillin (AMOX, 0.25-32) chloramphenicol (CHL, 2-16), amoxicillin/clavulanic acid 2:1 ratio (AUG2, 0.25/0.12-32/16), clindamycin (CLI, 0.5-64), rifampicin (RIF, 1-64), and imipenem (IMI, 0.12-64). The microplates were sealed with a micro-perforated film and incubated at $37^{\circ} \mathrm{C}$ for $48 \mathrm{~h}$ under anaerobic conditions. The reference strain CIP103409 ${ }^{\mathrm{T}}$ (Institut Pasteur Collection, Paris, France) was used as control. The antimicrobial profiles that were obtained on the two Sensititre ${ }^{\mathrm{TM}}$ plates are presented in Tables S2 and S3.

The lowest concentration at which no bacterial growth was detected corresponded to the minimum inhibitory concentration (MIC) value. MIC 50 and MIC 90 were the MIC values at which $50 \%$ and $90 \%$ of the isolates were inhibited.

\subsection{Statistical Analysis}

The MIC of the isolates for the tested antimicrobials was subjected to principal components analysis (PCA) to explore the relationship between the origin of the isolate (BGP, manure, digestate) and their antimicrobial resistance profiles. All of the statistical tests were performed with XLSTAT 2019 (Addinsoft, Bordeaux, France). Heatmap of normalized antimicrobial resistance were generated using the Complex Heat map package in Circlize in R [36].

\section{Results}

\subsection{Toxinotyping of C. perfringens Isolates}

Among the 157 isolates, 138 (88\%) carried the cpa gene (43 from BGP1, 47 from BGP2, and 48 from BGP3). As shown in Table 3, 108 (78.3\%) were type A, and $23(16.7 \%)$ were type G (netB gene). Both types were found in pig and dairy manure and in the digestate in all three BGPs. Five isolates $(3.6 \%)$ and two isolates (1.4\%), found only in BGP3, were type C (cpb gene) and type D (etx gene), respectively. The proportion of $C$. perfringens isolates harboring the $c p b 2$ gene were $48.1 \%, 50 \%, 56.5 \%$, and $80 \%$ for types A, D, G, and C, respectively. None of the isolates harbored both cpe and iap genes.

Table 3. Occurrence of the toxinotypes of $C$. perfringens isolates in manure and digestate in three biogas plants.

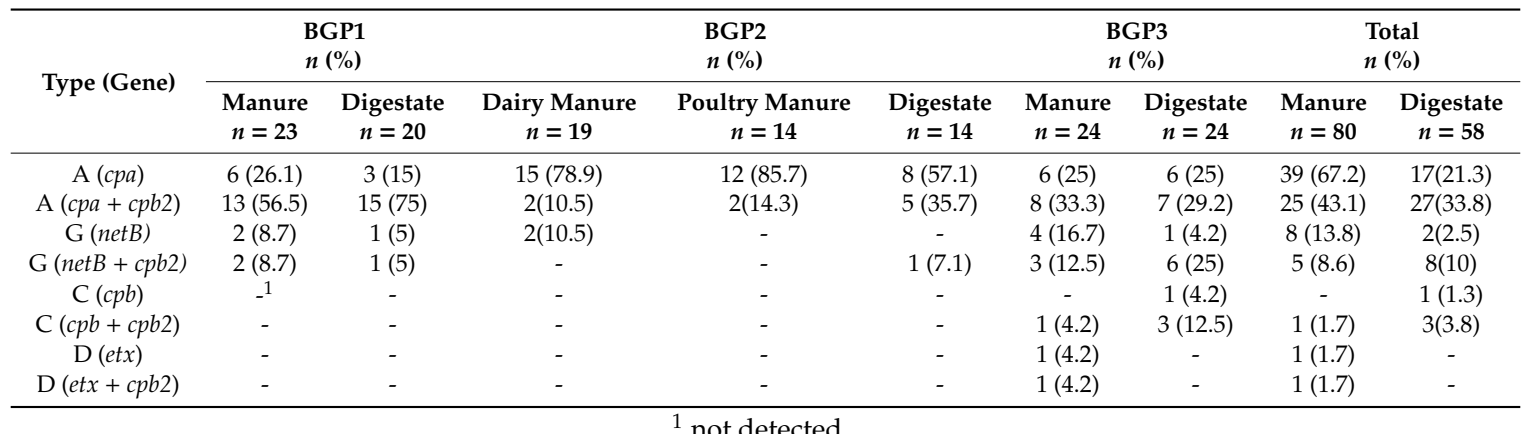




\subsection{Tetracycline and Erythromycin Resistance Genes of C. perfringens Isolates}

Both $\operatorname{tet} A(\mathrm{P})$ and $\operatorname{tet} B(\mathrm{P})$ genes were detected in the 138 cpa-positives isolates from manure and digestate of the three BGPs, but not in isolates from poultry manure (Table 4), whereas the erm $(\mathrm{Q})$ gene was only found in isolates from BGP1 and BGP3.

Table 4. Detection of antimicrobial resistance genes $(\operatorname{tet} A(\mathrm{P}), \operatorname{tet} B(\mathrm{P}), \operatorname{tet}(\mathrm{M})$, and $\operatorname{erm}(\mathrm{Q})$ genes) of isolates in manure and digestate in three biogas plants.

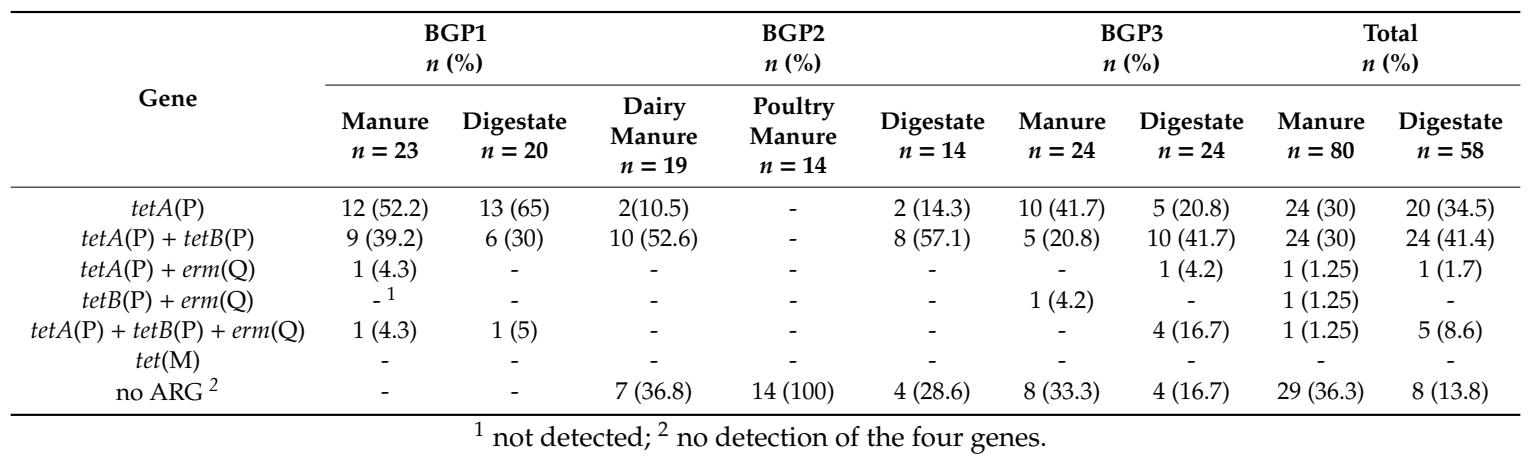

The most frequent gene, tet $A(\mathrm{P})$, was found in $62.5 \%$ and $86.2 \%$ of the isolates from the manure and digestate in the three BGPs, respectively. The $\operatorname{tet} B(\mathrm{P})$ gene was associated with $\operatorname{tet} A(\mathrm{P})$ genes in $31.3 \%$ and $50 \%$ of the isolates from manure and digestate, respectively. The erm $(\mathrm{Q})$ gene was found less frequently, i.e., in $3.8 \%$ of the isolates from manure and $10.3 \%$ of the isolates from digestate. No tet $(\mathrm{M})$ gene was detected in the isolates.

\subsection{Antimicrobial Susceptibility of C. perfringens Isolates}

The 138 cpa-positive isolates were subjected to antimicrobial resistance analysis while using the Sensititre ${ }^{\mathrm{TM}}$ bovine/porcine test system. Plots of the first and second PCA scores revealed no differences between the antimicrobial resistance profiles of the isolates originating from the manure (Figure 1A) and from the digestates (Figure 1B) of the three BGPs. However, 17 isolates originating from the three BGPs, which we clustered in five groups (I and II, Figure 1A; III to V, Figure 1B), differed from the other isolates by their high resistance to some of the antibiotics tested (Figure S1). Isolates from Group I $(n=3)$ differed by their high level of resistance to penicillin (MIC $>8 \mu \mathrm{g} / \mathrm{mL}$ ), ampicillin and clindamycin $(\mathrm{MIC} \geq 16 \mu \mathrm{g} / \mathrm{mL}$ ), tartrate tylosin and tiamulin (MIC $>32 \mu \mathrm{g} / \mathrm{mL}$ ), and tilmicosin (MIC $>64 \mu \mathrm{g} / \mathrm{mL}$ ). Isolates from Group II $(n=3)$ were highly resistant to clindamycin (MIC $\geq 16 \mu \mathrm{g} / \mathrm{mL}$ ), tilmicosin (MIC $>64 \mu \mathrm{g} / \mathrm{mL}$ ), and oxytetracycline (MIC $>8 \mu \mathrm{g} / \mathrm{mL}$ ). Isolates from Group III $(n=6)$ had a higher MIC for enrofloxacin and danofloxacin than the maximum concentration tested (MIC $>2 \mu \mathrm{g} / \mathrm{mL}$ and $>1 \mu \mathrm{g} / \mathrm{mL}$, respectively). Isolates from Group IV $(n=3)$ were highly resistant to both clindamycin (MIC $\geq 16 \mu \mathrm{g} / \mathrm{mL}$ ) and tilmicosin (MIC $>64 \mu \mathrm{g} / \mathrm{mL}$ ). Isolates from Group V $(n=2)$ were highly resistant to oxytetracycline (MIC $>8 \mu \mathrm{g} / \mathrm{mL}$ ), clindamycin (MIC $>16 \mu \mathrm{g} / \mathrm{mL}$ ), and tilmicosin $(>64 \mu \mathrm{g} / \mathrm{mL}$ ).

The antimicrobial resistance profiles of the isolates varied considerably in the biogas plants, regardless of their origin (manure or digestate) (Figure S1). However, the MIC distribution of isolates from manure was close to that of isolates from digestate (Table 5, Figure S2).

With the exception of tulathromycin, the MICs of the isolates covered the dilution range tested for all antimicrobials (Table 5). Most of the isolates were susceptible to $\beta$-lactam and macrolides, except tulathromycin (with a MIC 50 value of $64 \mu \mathrm{g} / \mathrm{mL}$ ). Enrofloxacin and danofloxacin had low MIC 50 values of $0.25-0.5$ and $1 \mu \mathrm{g} / \mathrm{mL}$, respectively. Most of the isolates exhibited sensitivity to chlortetracycline with a MIC 50 value of $\leq 0.50 \mu \mathrm{g} / \mathrm{mL}$ in manure and of $1 \mu \mathrm{g} / \mathrm{mL}$ in digestate. The MIC 50 values of oxytetracycline were higher $(1 \mu \mathrm{g} / \mathrm{mL}$ in manure and $8 \mu \mathrm{g} / \mathrm{mL}$ in digestate).

Moreover, the growth of $19 \%$ of C. perfringens isolates was inhibited by sulfadimethoxine (Figure S1). Among the highly resistant group I to V, 14 isolates were tested on microplates that contained 
antibiotics used in human medicine (Table S3). Five of the tested isolates present in BGP2 and BGP3, showed high resistance to human antibiotics including imipenem, linezolid, amoxicillin-clavulanate, chloramphenicol, moxifloxacin, tigecycline, and vancomycin.
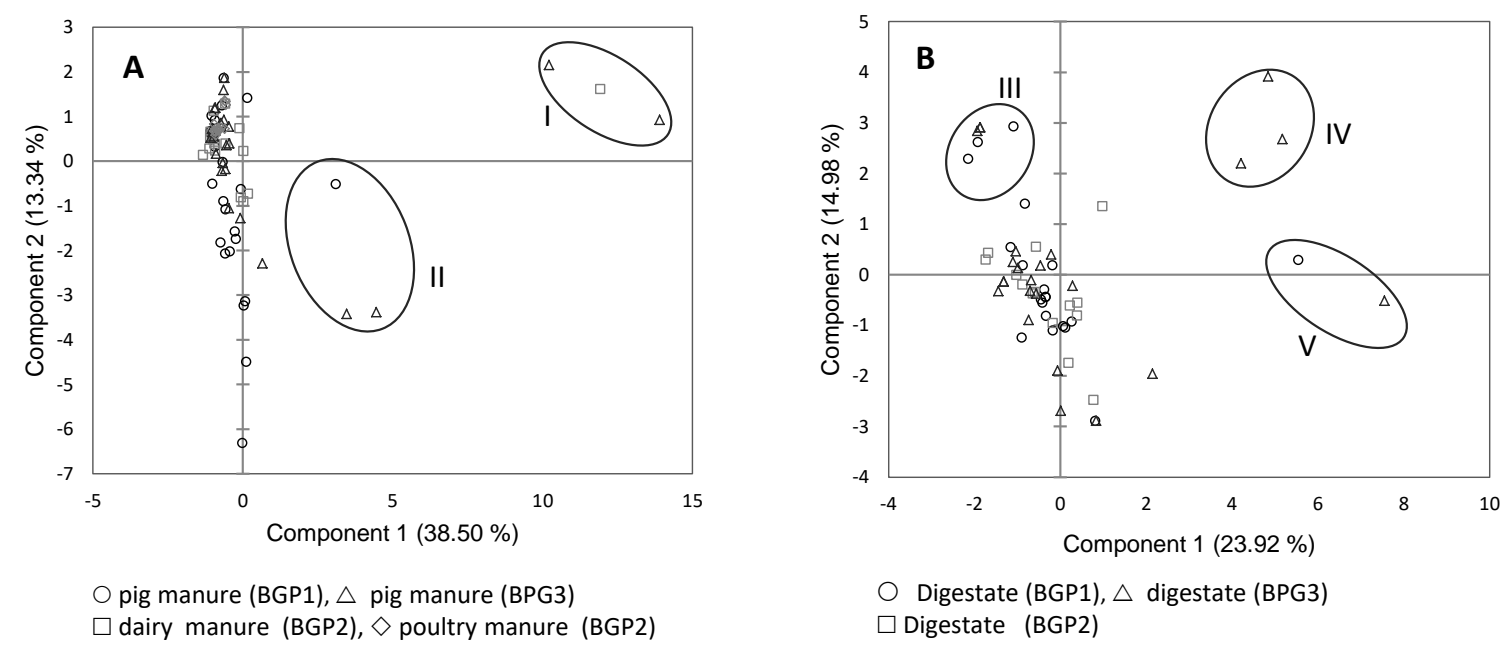

Figure 1. Principal components analysis (PCA) of antimicrobial resistance profiles of C. perfringens isolates from manure (A) and digestate (B) in three BGPs. Groups I to V contained highly resistant isolates.

Table 5. Minimum inhibitory concentration (MIC) distribution $(\mu \mathrm{g} / \mathrm{mL})$ of 13 antimicrobials tested against 138 isolates of $C$. perfringens originating from three BPGs.

\begin{tabular}{|c|c|c|c|c|c|c|c|c|c|}
\hline & \multirow{3}{*}{$\begin{array}{l}\text { Antimicrobial } \\
\text { Agents }\end{array}$} & \multicolumn{8}{|c|}{ Origin of Isolates } \\
\hline & & \multicolumn{4}{|c|}{ Manure $(n=80)$} & \multicolumn{4}{|c|}{ Digestate $(n=58)$} \\
\hline & & MIC50 & MIC90 & Min & Max & MIC50 & MIC90 & Min & Max \\
\hline \multirow{3}{*}{$\beta$-lactams } & Penicillin & $\leq 0.125$ & 1 & $\leq 0.125$ & $>8$ & $\leq 0.125$ & 0.5 & $\leq 0.125$ & 1 \\
\hline & Ampicillin & $\leq 0.25$ & $\leq 0.25$ & $\leq 0.25$ & $>16$ & $\leq 0.25$ & $\leq 0.25$ & $\leq 0.25$ & 2 \\
\hline & Ceftiofur & $\leq 0.25$ & 1 & $\leq 0.25$ & 4 & $\leq 0.25$ & 2 & $\leq 0.25$ & 2 \\
\hline \multirow[t]{3}{*}{ Macrolides } & Tartrate Tylosin & $\leq 0.5$ & 4 & $\leq 0.5$ & $>32$ & $\leq 0.5$ & 8 & $\leq 0.5$ & 16 \\
\hline & Tilmicosin & $\leq 4$ & 8 & $\leq 4$ & $>64$ & $\leq 4$ & $\leq 4$ & $\leq 4$ & $>64$ \\
\hline & Tulathromycin & 64 & $>64$ & 16 & $>64$ & 64 & $>64$ & 32 & $>64$ \\
\hline Lincosamides & Clindamycin & 2 & 2 & $\leq 0.25$ & $>16$ & 2 & 4 & $\leq 0.25$ & $>16$ \\
\hline \multirow[t]{2}{*}{ Fluoroquinolones } & Enrofloxacin & 0.25 & $>2$ & 0.25 & $>2$ & 0.50 & $>2$ & $\leq 0.125$ & $>2$ \\
\hline & Danofloxacin & 1 & $>1$ & 0.25 & $>1$ & 1 & $>1$ & 0.5 & $>1$ \\
\hline Pleuromutilins & Tiamulin & 4 & 8 & $\leq 0.5$ & $>32$ & 4 & 16 & $\leq 0.5$ & $>32$ \\
\hline Phenicols & Florfenicol & 1 & 2 & 0.5 & $>8$ & 1 & 1 & $\leq 0.25$ & 2 \\
\hline \multirow[t]{2}{*}{ Tetracyclines } & Chlortetracycline & $\leq 0.5$ & 8 & $\leq 0.5$ & $>8$ & 1 & 4 & $\leq 0.5$ & 8 \\
\hline & Oxytetracycline & 2 & $>8$ & $\leq 0.5$ & $>8$ & 8 & $>8$ & $\leq 0.5$ & $>8$ \\
\hline
\end{tabular}

\section{Discussion}

Although digestates from biogas plants fed with manure contain high levels of $C$. perfringens (ca. $10^{4} \mathrm{CFU} / \mathrm{g}$ ) [32-37], no information is available on the range of toxin genes and the antimicrobial profiles of this pathogenic bacterium in agricultural digestate that is intended for land application. This is the first study to assess digestate as a potential carrier of virulent and multiresistant C. perfringens.

\subsection{Toxinotyping of C. perfringens Isolates}

The dominance of type $\mathrm{A}$ isolates in both manure and digestate is in agreement with the high prevalence of this toxinotype in farm animals [38-40]. Although the cpe gene was not detected in either manure or digestate, the three BGPs produced digestate containing virulent $C$. perfringens. Indeed, half the type A isolates from the three BGPs carried the $c p b 2$ gene encoding the $\beta 2$ toxin, which is reported to be associated with diarrheal diseases $[19,41]$. This result is consistent with those 
of studies that were conducted on farm animals, in which between $39 \%$ and $78.8 \%$ frequency of the $c p a$ gene together with $c p b 2$ gene was observed [25,42-44]. Moreover, some isolates recovered from manure and digestate were positive for $c p b$, etx, and netB genes. Conversely, Chan et al. [45] did not detect these genes in fecal and manure samples collected from pig farms. Type $C(c p a+c p b$ genes) and type $\mathrm{D}(\mathrm{cpa}+$ et $x$ genes), both associated with farm animal diseases, were detected at a low frequencies only in isolates from the BGP3 digestate. Type G (cpa and netB genes), responsible for necrotic enteritis in chickens $[6,29,45]$, was carried by isolates from all three BGPs, showing that land application of digestate can contribute to the dissemination of $C$. perfringens carrying net $B$ in the agricultural environment.

\subsection{Tetracycline and Erythromycin Resistance Genes of C. perfringens Isolates}

The occurrence of resistance genes and the antimicrobial susceptibility of C. perfringens of environmental origin have rarely been studied. In this study, although the tet $(\mathrm{M})$ gene was not detected in digestate, the tet $A(\mathrm{P})$ gene alone and double resistance tet $A(\mathrm{P})$-tet $B(\mathrm{P})$ genes were found in $34.5 \%$ and $41.4 \%$ of the isolates, respectively. Their prevalence in digestates was slightly higher than that reported in other matrices. Indeed, Kiu et al. [14] observed a frequency of detection of $\operatorname{tet} A(\mathrm{P})$ alone and of the tet $A(\mathrm{P})-\operatorname{tet} B(\mathrm{P})$ gene of $14.8 \%$ and $35.2 \%$ in isolates from broiler chickens, respectively. In another study, they were detected in $26 \%$ and $22 \%$ of isolates of environmental origin (soils, water, and sewage) [8]. The proportion of isolates carrying the $\operatorname{erm}(\mathrm{Q})$ gene (13.6\%) in the digestates of the two BGPs fed with pig manure was also higher than that previously observed in isolates that were collected from broiler chickens $(4.5 \%)$ and in environmental samples $(1 \%)[8,14]$.

\subsection{Antimicrobial Susceptibility of C. perfringens Isolates}

In addition to their natural resistance to aminoglycosides, $C$. perfringens showed significant resistance to tetracycline, which has been associated with the presence of $\operatorname{tet} A(\mathrm{P}), \operatorname{tet} B(\mathrm{P})$, and tet $(\mathrm{M})$ genes [27]. In this study, the isolates were more resistant to oxytetracycline than to chlortetracycline (Table 5), in agreement with the studies of Martel et al. [46] and Ngamwongsatit et al. [38] who reported that chlortetracycline was more active than oxytetracycline against C. perfringens isolated from chickens and from neonatal piglets, respectively. It is noteworthy that $7.4 \%$ of the isolates with a MIC $\geq 4 \mu \mathrm{g} / \mathrm{mL}$ for chlortetracycline and with a MIC $\geq 8 \mu \mathrm{g} / \mathrm{mL}$ for oxytetracycline harbored none of the three target genes $(\operatorname{tet} A(\mathrm{P}), \operatorname{tet} B(\mathrm{P})$, and $\operatorname{tet}(\mathrm{M}))$. This could be explained by the presence of other tetracycline resistance genes. Indeed, $\operatorname{tet}(\mathrm{K})$ and tet $(\mathrm{L})$ have been detected at low frequencies in isolates from broilers $[46,47]$. Moreover, $4.4 \%$ of the isolates that were susceptible to both chlortetracycline and oxytetracycline (MIC $\leq 0.5 \mu \mathrm{g} / \mathrm{mL}$ ) carried the $\operatorname{tet} A(\mathrm{P})-\operatorname{tet} B(\mathrm{P})$ genes and $22.2 \%$ carried the $\operatorname{tet} A(\mathrm{P})$ gene. The inconsistency between the MIC values and the presence of genetic tetracycline resistance determinants has already been pointed out $[7,24,47]$. The reason for the presence of sensitive isolates harboring $\operatorname{tet} A(\mathrm{P})$ and/or $\operatorname{tet} B(\mathrm{P})$ is unclear. This may be due to lack of expression or to point mutation, as suggested by Kather et al. [7] and Gholamiandehkordi et al. [47]. In the present study, all strains were highly resistant to tulathromycin, a macrolide antibiotic used to treat bovine and swine respiratory diseases [48]. However, it was not possible to determine the antibiotic use in the three farms whose manure was treated by anaerobic digestion. On the whole, the MIC 50 observed in manure and digestates for the antibiotic tested resembled those reported in animal feces $[22,27,29,38,49,50]$, suggesting that storing manure and anaerobic digestion have no impact on the antimicrobial susceptibility of $C$. perfringens originating from farm animals.

Among the C. perfringens isolates from the three BGPs, $12.3 \%$ were highly resistant to some of the antibiotics tested. Five of the 14 isolates tested with the Sensititre ${ }^{\mathrm{TM}}$ Anaerobe MIC plate (four from BGP3, one from BGP2) were also highly resistant to human antimicrobial medicine (Table S3). Based on the values of the EUCAST anaerobe MIC breakpoints reported by Pence et al. [13], these isolates were resistant to metronidazole, clindamycin, and penicillin (MIC $\geq 8 \mu \mathrm{g} / \mathrm{mL}$ ), to chloramphenicol, amoxicillin-clavulanate, and imipenem (MIC $\geq 16 \mu \mathrm{g} / \mathrm{mL}$ ), 
and to piperacillin-tazobactam (MIC $>64 \mu \mathrm{g} / \mathrm{mL}$ ). High MIC were also observed for vancomycin (MIC $>8 \mu \mathrm{g} / \mathrm{mL}$ ), which is normally low for clostridia, and for moxifloxacin (MIC $>4 \mu \mathrm{g} / \mathrm{mL}$ ), the resistance to which is reported to be increasing [13].

In this study, digestates were collected from digesters fed with manure, which is the first step of the process of anaerobic digestion. Indeed, post-treatments of raw digestates involved either storage in a tank, post-digestion (BGP2), or mechanical separation of the solid fraction before composting and storage of the liquid fraction (BGP1). It has been reported that post-digestion and mechanical separation do not reduce the concentration of $C$. perfringens [37], contrary to manure composting [3,51]. Moreover, the legal requirement for heat treatment $\left(70{ }^{\circ} \mathrm{C}\right.$ for $1 \mathrm{~h}$ ) according to the EU animal by-products regulation (EU Commission Regulation (EU) No 142/2011) is not sufficient for eliminating spores of $C$. perfringens. Indeed, Sahlström et al. [52] reported that the number of $C$. perfringens was not significantly affected by this time-temperature condition. On the opposite, high temperatures $\left(135^{\circ} \mathrm{C}\right.$ to $190^{\circ} \mathrm{C}$ ) pre-treatments performed in order to increase accessibility of the enzymes to the substrate and, therefore, to enhance biogas production $[53,54]$, may reduce the concentration of $C$. perfringens. Actually, the inactivation of $C$. perfringens spores can be achieved at temperatures of $110{ }^{\circ} \mathrm{C}$ [55]. Thus, high temperature pre-treatment or digestate composting may be applied to avoid C. perfringens spreading in soils.

\section{Conclusions}

The results of this study revealed that both manure and digestates contained C. perfringens isolates belonging types $\mathrm{C}, \mathrm{D}$, and $\mathrm{G}$, which may be pathogenic for human or animals. Moreover, the presence in the digestates of some isolates highly resistant to antibiotics used in both veterinary and human medicine may increase the burden of antimicrobial resistance in agroecosystems, as $C$. perfringens could be involved in horizontal gene transfer from enteric bacteria to bacterial soil populations.

Supplementary Materials: The following are available online at http://www.mdpi.com/1660-4601/17/15/5450/s1, Figure S1: Heatmap of antimicrobial resistance profiles of $C$. perfringens isolates from three biogas plants, Figure S2: MIC distribution of 13 antimicrobials in manure and raw digestate in three BGPs, Table S1: Process parameters of the three biogas plants, Table S2: MIC of C. perfringens CIP $103409^{\mathrm{T}}$ obtained on Sensititre ${ }^{\mathrm{TM}}$ Bovine/porcine $(\mu \mathrm{g} / \mathrm{mL})$, Table S3: MIC of selection of isolates (belonging to groups I to V) from the three BGP and of the reference strain CIP $103409^{\mathrm{T}}$ obtained on Sentititre ${ }^{\mathrm{TM}}$ FRAM1ANA $(\mu \mathrm{g} / \mathrm{mL})$.

Author Contributions: Author contributions were as follows: A.-M.P. and L.D.: conceptualization, methodology, validation, formal analysis; C.Z. and L.D.: performing the experiments; All authors: resources; L.D.: writing-Original draft preparation; A.-M.P., C.D. and C.L.M.: writing-Review and editing, supervision, funding acquisition; A.-M.P. and C.D.: project administration. All authors have read and agreed to the published version of the manuscript.

Funding: This research was funded by the French Environment and Energy Management Agency (ADEME), grant number 1606C0022.

Acknowledgments: The authors are grateful to the participating farmers. The authors also thank Olivier Firmesse and Frédéric Barbut for providing the reference strains. L.D. is recipient of an Irstea-Région Bretagne fellowship.

Conflicts of Interest: The authors declare no conflict of interest.

\section{References}

1. Annual Statistical Report; European Biogas Association: Gent, Belgium, 2019.

2. Johansson, A.; Aspan, A.; Bagge, E.; Båverud, V.; Engström, B.E.; Johansson, K.-E. Genetic diversity of Clostridium perfringens type A isolates from animals, food poisoning outbreaks and sludge. BMC Microbiol. 2006, 6, 47. [CrossRef] [PubMed]

3. Gómez-Brandón, M.; Juárez, M.F.-D.; Zangerle, M.; Insam, H. Effects of digestate on soil chemical and microbiological properties: A comparative study with compost and vermicompost. J. Hazard. Mater. 2016, 302, 267-274. [CrossRef] 
4. Lau, C.H.-F.; Li, B.; Zhang, T.; Tien, Y.-C.; Scott, A.; Murray, R.; Sabourin, L.; Lapen, D.R.; Duenk, P.; Topp, E. Impact of pre-application treatment on municipal sludge composition, soil dynamics of antibiotic resistance genes, and abundance of antibiotic-resistance genes on vegetables at harvest. Sci. Total Environ. 2017, 587, 214-222. [CrossRef] [PubMed]

5. Scott, A.; Tien, Y.-C.; Drury, C.F.; Reynolds, W.D.; Topp, E. Enrichment of antibiotic resistance genes in soil receiving composts derived from swine manure, yard wastes, or food wastes, and evidence for multiyear persistence of swine Clostridium spp. Can. J. Microbiol. 2018, 64, 201-208. [CrossRef] [PubMed]

6. Leclercq, S.O.; Wang, C.; Sui, Z.; Wu, H.; Zhu, B.; Deng, Y.; Feng, J. A multiplayer game: Species of Clostridium, Acinetobacter, and Pseudomonas are responsible for the persistence of antibiotic resistance genes in manure-treated soils: Antibiotic resistance genes in manure-treated soils. Environ. Microbiol. 2016, 18, 3494-3508. [CrossRef]

7. Kather, E.J.; Marks, S.L.; Foley, J.E. Determination of the prevalence of antimicrobial resistance genes in canine Clostridium perfringens isolates. Vet. Microbiol. 2006, 113, 97-101. [CrossRef]

8. Soge, O.O.; Tivoli, L.D.; Meschke, J.S.; Roberts, M.C. A conjugative macrolide resistance gene mef (A), in environmental Clostridium perfringens carrying multiple macrolide and/or tetracycline resistance genes. J. Appl. Microbiol. 2009, 106, 34-40. [CrossRef] [PubMed]

9. Alegbeleye, O.O.; Sant'Ana, A.S. Manure-borne pathogens as an important source of water contamination: An update on the dynamics of pathogen survival/transport as well as practical risk mitigation strategies. Int. J. Hyg. Environ. Health 2020, 227, 113524. [CrossRef]

10. Nag, R.; Auer, A.; Markey, B.K.; Whyte, P.; Nolan, S.; O’Flaherty, V.; Russell, L.; Bolton, D.; Fenton, O.; Richards, K.; et al. Anaerobic digestion of agricultural manure and biomass-Critical indicators of risk and knowledge gaps. Sci. Total Environ. 2019, 690, 460-479. [CrossRef]

11. Hamza, D.; Dorgham, S.M.; Elhariri, M.; Elhelw, R.; Ismael, E. New insight of apparently healthy animals as a potential reservoir for Clostridium perfringens: A public health implication. J. Vet. Res. 2018, 62, 457-462. [CrossRef]

12. Tango, C.N.; Wei, S.; Khan, I.; Hussain, M.S.; Kounkeu, P.-F.N.; Park, J.; Kim, S.; Oh, D.H. Microbiological Quality and Safety of Fresh Fruits and Vegetables at Retail Levels in Korea. J. Food Sci. 2018, 83, 386-392. [CrossRef] [PubMed]

13. Pence, M.A. Antimicrobial Resistance in Clinically Important Anaerobes. Clin. Microbiol. Newsl. 2019, 41, 1-7. [CrossRef]

14. Kiu, R.; Brown, J.; Bedwell, H.; Leclaire, C.; Caim, S.; Pickard, D.; Dougan, G.; Dixon, R.A.; Hall, L.J. Genomic analysis on broiler-associated Clostridium perfringens strains and exploratory caecal microbiome investigation reveals key factors linked to poultry necrotic enteritis. Anim. Microbiome 2019, 1, 12. [CrossRef] [PubMed]

15. Rood, J.I.; Adams, V.; Lacey, J.; Lyras, D.; McClane, B.A.; Melville, S.B.; Moore, R.J.; Popoff, M.R.; Sarker, M.R.; Songer, J.G.; et al. Expansion of the Clostridium perfringens toxin-based typing scheme. Anaerobe 2018, 53, 5-10. [CrossRef]

16. Centers for Disease Control and Prevention (CDC). Surveillance for Foodborne Disease Outbreaks, United States, 2017; CDC: Atlanta, GA, USA, 2019; p. 10.

17. Anonymous Santé Publique France/Le point Épidémio/Surveillance des Toxi-Infections Alimentaires Collectives. Données de la Déclaration Obligatoire 2018; Santé Publique: Saint-Maurice, France, 2019; p. 12.

18. Freedman, J.C.; Theoret, J.R.; Wisniewski, J.A.; Uzal, F.A.; Rood, J.I.; McClane, B.A. Clostridium perfringens type A-E toxin plasmids. Res. Microbiol. 2015, 166, 264-279. [CrossRef]

19. Uzal, F.A.; Navarro, M.A.; Li, J.; Freedman, J.C.; Shrestha, A.; McClane, B.A. Comparative pathogenesis of enteric clostridial infections in humans and animals. Anaerobe 2018, 53, 11-20. [CrossRef]

20. Fisher, D.J.; Miyamoto, K.; Harrison, B.; Akimoto, S.; Sarker, M.R.; McClane, B.A. Association of beta2 toxin production with Clostridium perfringens type A human gastrointestinal disease isolates carrying a plasmid enterotoxin gene: cpb2/cpe -positive C. perfringens disease isolates. Mol. Microbiol. 2005, 56, 747-762. [CrossRef]

21. Rood, J.I.; Buddle, J.R.; Wales, A.J.; Sidhu, R. The occurrence of antibiotic resistance in Clostridium perfringens from pigs. Aust. Vet. J. 1985, 62, 276-279. [CrossRef]

22. Slavić, Đ.; Boerlin, P.; Fabri, M.; Klotins, K.C.; Zoethout, J.K.; Weir, P.E.; Bateman, D. Antimicrobial susceptibility of Clostridium perfringens isolates of bovine, chicken, porcine, and turkey origin from Ontario. Can. J. Vet. Res. 2011, 75, 89-97. 
23. Adams, V.; Han, X.; Lyras, D.; Rood, J.I. Antibiotic resistance plasmids and mobile genetic elements of Clostridium perfringens. Plasmid 2018, 99, 32-39. [CrossRef]

24. Johansson, A.; Greko, C.; Engström, B.E.; Karlsson, M. Antimicrobial susceptibility of Swedish, Norwegian and Danish Clostridium perfringens from poultry, and distribution of tetracycline resistance genes. Vet. Microbiol. 2004, 99, 251-257. [CrossRef] [PubMed]

25. Park, M.; Rafii, F. The prevalence of plasmid-coded cpe enterotoxin, $\beta 2$ toxin, tpeL toxin, and tetracycline resistance in Clostridium perfringens strains isolated from different sources. Anaerobe 2019, 56, 124-129. [CrossRef] [PubMed]

26. Berryman, D.I.; Lyristis, M.; Rood, J.I. Cloning and sequence analysis of ermQ, the predominant macrolidelincosamide-streptogramin B resistance gene in Clostridium perfringens. Antimicrob. Agents Chemother. 1994, 38, 1041-1046. [CrossRef] [PubMed]

27. Sasaki, Y.; Yamamoto, K.; Tamura, Y.; Takahashi, T. Tetracycline-resistance genes of Clostridium perfringens, Clostridium septicum, and Clostridium sordellii isolated from cattle affected with malignant edema. Vet. Microbiol. 2001, 83, 61-69. [CrossRef]

28. Park, M.; Rooney, A.P.; Hecht, D.W.; Li, J.; McClane, B.A.; Nayak, R.; Paine, D.D.; Rafii, F. Phenotypic and genotypic characterization of tetracycline and minocycline resistance in Clostridium perfringens. Arch. Microbiol. 2010, 192, 803-810. [CrossRef]

29. Salvarani, F.M.; Silva, R.O.S.; Pires, P.S.; Cruz Júnior, E.C.D.C.; Albefaro, I.S.; Guedes, R.M.D.C.; Lobato, F.C.F. Antimicrobial susceptibility of Clostridium perfringens isolated from piglets with or without diarrhea in Brazil. Braz. J. Microbiol. 2012, 43, 1030-1033. [CrossRef]

30. Voidarou, C.; Bezirtzoglou, E.; Alexopoulos, A.; Plessas, S.; Stefanis, C.; Papadopoulos, I.; Vavias, S.; Stavropoulou, E.; Fotou, K.; Tzora, A.; et al. Occurrence of Clostridium perfringensfrom different cultivated soils. Anaerobe 2011, 17, 320-324. [CrossRef]

31. Lloret, E.; Salar, M.J.; Blaya, J.; Pascual, J.A. Two-stage mesophilic anaerobic-thermophilic digestion for sludge sanitation to obtain advanced treated sludge. Chem. Eng. J. 2013, 230, 59-63. [CrossRef]

32. Le Maréchal, C.; Druilhe, C.; Repérant, E.; Boscher, E.; Rouxel, S.; Le Roux, S.; Poëzévara, T.; Ziebal, C.; Houdayer, C.; Nagard, B.; et al. Evaluation of the occurrence of sporulating and non-sporulating pathogenic bacteria in manure and in digestate of five agricultural biogas plants. Microbiology 2019, 8. [CrossRef]

33. Anonymous ISO 7937: 2005-02: Microbiology of Food and Animal Feeding Stuffs-Horizontal Method for the Enumeration of Clostridium perfringens-Colony-Count Technique; International Standard Organization: Geneva, Switzerland, 2005.

34. Keyburn, A.L.; Boyce, J.D.; Vaz, P.; Bannam, T.L.; Ford, M.E.; Parker, D.; Di Rubbo, A.; Rood, J.I.; Moore, R.J. NetB. a New Toxin That Is Associated with Avian Necrotic Enteritis Caused by Clostridium perfringens. PLoS Pathog. 2008, 4, e26. [CrossRef]

35. Baums, C.G.; Schotte, U.; Amtsberg, G.; Goethe, R. Diagnostic multiplex PCR for toxin genotyping of Clostridium perfringens isolates. Vet. Microbiol. 2004, 100, 11-16. [CrossRef]

36. Gu, Z.; Eils, R.; Schlesner, M. Complex heatmaps reveal patterns and correlations in multidimensional genomic data. Bioinformatics 2016, 32, 2847-2849. [CrossRef] [PubMed]

37. Orzi, V.; Scaglia, B.; Lonati, S.; Riva, C.; Boccasile, G.; Alborali, G.L.; Adani, F. The role of biological processes in reducing both odor impact and pathogen content during mesophilic anaerobic digestion. Sci. Total Environ. 2015, 526, 116-126. [CrossRef] [PubMed]

38. Ngamwongsatit, B.; Tanomsridachchai, W.; Suthienkul, O.; Urairong, S.; Navasakuljinda, W.; Janvilisri, T. Multidrug resistance in Clostridium perfringens isolated from diarrheal neonatal piglets in Thailand. Anaerobe 2016, 38, 88-93. [CrossRef]

39. Fohler, S.; Klein, G.; Hoedemaker, M.; Scheu, T.; Seyboldt, C.; Campe, A.; Jensen, K.C.; Abdulmawjood, A. Diversity of Clostridium perfringens toxin-genotypes from dairy farms. BMC Microbiol. 2016, 16. [CrossRef]

40. Zhang, T.; Zhang, W.; Ai, D.; Zhang, R.; Lu, Q.; Luo, Q.; Shao, H. Prevalence and characterization of Clostridium perfringens in broiler chickens and retail chicken meat in central China. Anaerobe 2018, 54, 100-103. [CrossRef]

41. Freedman, J.; Shrestha, A.; McClane, B. Clostridium perfringens Enterotoxin: Action, Genetics, and Translational Applications. Toxins 2016, 8, 73. [CrossRef] 
42. Hashimoto, A.; Tsuchioka, H.; Higashi, K.; Ota, N.; Harada, H. Distribution of Enterotoxin Gene-positive Clostridium perfringens Spores among Human and Livestock Samples and its Potential as a Human Fecal Source Tracking Indicator. J. Water Environ. Technol. 2016, 14, 447-454. [CrossRef]

43. Yadav, J.P.; Das, S.C.; Dhaka, P.; Vijay, D.; Kumar, M.; Mukhopadhyay, A.K.; Chowdhury, G.; Chauhan, P.; Singh, R.; Dhama, K.; et al. Molecular characterization and antimicrobial resistance profile of Clostridium perfringens type A isolates from humans, animals, fish and their environment. Anaerobe 2017, 47, 120-124. [CrossRef]

44. Yang, W.-Y.; Chou, C.-H.; Wang, C. Characterization of toxin genes and quantitative analysis of netB in necrotic enteritis (NE)-producing and non-NE-producing Clostridium perfringens isolated from chickens. Anaerobe 2018, 54, 115-120. [CrossRef]

45. Chan, G.; Farzan, A.; Soltes, G.; Nicholson, V.M.; Pei, Y.; Friendship, R.; Prescott, J.F. The epidemiology of Clostridium perfringens type A on Ontario swine farms, with special reference to $c p b 2$-positive isolates. BMC Vet. Res. 2012, 8, 156. [CrossRef] [PubMed]

46. Martel, A.; Devriese, L.; Cauwerts, K.; De Gussem, K.; Decostere, A.; Haesebrouck, F. Susceptibility of Clostridium perfringens strains from broiler chickens to antibiotics and anticoccidials. Avian Pathol. 2004, 33, 3-7. [CrossRef] [PubMed]

47. Gholamiandehkordi, A.; Eeckhaut, V.; Lanckriet, A.; Timbermont, L.; Bjerrum, L.; Ducatelle, R.; Haesebrouck, F.; Van Immerseel, F. Antimicrobial resistance in Clostridium perfringens isolates from broilers in Belgium. Vet. Res. Commun. 2009, 33, 1031-1037. [CrossRef]

48. Villarino, N.; Brown, S.A.; Martín-Jiménez, T. The role of the macrolide tulathromycin in veterinary medicine. Vet. J. 2013, 198, 352-357. [CrossRef] [PubMed]

49. Llanco, L.; Nakano, V.; Ajp, F.; Mj, A.-C. Toxinotyping and antimicrobial susceptibility of Clostridium perfringens isolated from broiler chickens with necrotic enteritis. Int. J. Micr. Res. 2012, 4, 290-294. [CrossRef]

50. Oliveira Júnior, C.A.D.; Silva, R.O.S.; Diniz, A.N.; Pires, P.S.; Salvarani, F.M.; Assis, R.A.D.; Lobato, F.C.F. Antimicrobial susceptibility of Clostridium perfringens isolated from domestic and wild animal species in Brazil. Semina Ciências Agrárias 2016, 37, 257. [CrossRef]

51. Tien, Y.-C.; Li, B.; Zhang, T.; Scott, A.; Murray, R.; Sabourin, L.; Marti, R.; Topp, E. Impact of dairy manure pre-application treatment on manure composition, soil dynamics of antibiotic resistance genes, and abundance of antibiotic-resistance genes on vegetables at harvest. Sci. Total Environ. 2017, 581, 32-39. [CrossRef]

52. Sahlström, L.; Bagge, E.; Emmoth, E.; Holmqvist, A.; Danielsson-Tham, M.-L.; Albihn, A. A laboratory study of survival of selected microorganisms after heat treatment of biowaste used in biogas plants. Bioresour. Technol. 2008, 99, 7859-7865. [CrossRef]

53. Carrère, H.; Antonopoulou, G.; Affes, R.; Passos, F.; Battimelli, A.; Lyberatos, G.; Ferrer, I. Review of feedstock pretreatment strategies for improved anaerobic digestion: From lab-scale research to full-scale application. Bioresour. Technol. 2016, 199, 386-397. [CrossRef]

54. Carrère, H.; Sialve, B.; Bernet, N. Improving pig manure conversion into biogas by thermal and thermo-chemical pretreatments. Bioresour. Technol. 2009, 100, 3690-3694. [CrossRef]

55. Talukdar, P.K.; Udompijitkul, P.; Hossain, A.; Sarker, M.R. Inactivation Strategies for Clostridium perfringens Spores and Vegetative Cells. Appl. Envion. Microbiol. 2017, 83, e02731-16. [CrossRef] [PubMed]

(C) 2020 by the authors. Licensee MDPI, Basel, Switzerland. This article is an open access article distributed under the terms and conditions of the Creative Commons Attribution (CC BY) license (http://creativecommons.org/licenses/by/4.0/). 